\title{
Influence of surface treatment on bond strength of resin cements to a nickel alloy
}

\author{
Influência do tratamento de superfície na resistência de união de cimentos resinosos em liga de níquel
}

Camilla Bottino da SILVA ${ }^{1}$

Daniel de Mattos SALIM ${ }^{1}$

Gabriel Maia KAMMER ${ }^{1}$

Waldimir CARVALHO ${ }^{1}$

Cresus Vinicius Depes de GOUVÊA ${ }^{1}$

\section{ABSTRACT}

Objective

To compare the bond strength of two dual-cure resin cements to Ni-Cr alloy test specimens (TS), with and without surface treatment.

\section{Methods}

RelyX ARC and Panavia Fluoro Cements were tested. Eighty nickel alloy TS were cast, measuring $10 \mathrm{~mm} \times 7 \mathrm{~mm} \times 2.5 \mathrm{~mm}$, forming a total of 40 pairs. Four groups of TS were obtained. Twenty pairs were treated by airborne abrasion with 50 um aluminum oxide particles and 20 did not undergo treatment. The TS were cleaned usingultrasound. The parts were cemented according to manufacturers' instructions. A shear bond strength test was performed until bond failure occurred.

Results

Analysis of variance (ANOVA) showed there was a statistical difference ( $p>0.05)$ between thegroups. Visual analysis of optical microscopy images showed a mixed fracture pattern with adhesive predominance for RelyX ARC, and mixed with cohesive predominance for Panavia F. The sandblasted groups obtained better bonding, with Panavia F attaining higher bond-strength values than RelyX ARC.

\section{Conclusion}

The Ni-Cr alloy/Panavia F on a treated surface behaved better in terms of bonding.

Indexing terms: Composite resins. Dental cements. Shear bond strength.

\section{RESUMO}

\section{Objetivo}

Comparar a força de adesão de dois cimentos resinosos duais em liga de Ni-Cr, em corpos de prova (CP) com e sem tratamento de superfície.

\section{Métodos}

Os cimentos Rely-X ARC e Panavia Fluoro Cement foram testados. Oitenta CP foram fundidos em liga de níquel, nas dimensões $10 \mathrm{~mm} \times 7 \mathrm{~mm}$ x 2,5mm em um total de 40 pares. Quatro grupos de CP foram obtidos. Vinte pares foram tratados com jato de alumínio de $50 \mu \mathrm{m}$ e 20 sem tratamento. Os CP foram limpos em ultrassom. As peças foram cimentadas conforme instruções dos fabricantes. O ensaio de cisalhamento foi conduzido até o momento da falha adesiva.

\section{Resultados}

A análise da variância (ANOVA) mostrou que houve diferença estatística (p>0,05) entre os grupos. A análise visual das imagens de microscopia óptica mostrou um padrão de fratura mista com predomínio adesiva para o Rely-X ARC e mista com predomínio coesiva para o Panavia F. Os grupos jateados obtiveram melhor adesividade, onde o Panavia F alcançou valores maiores que o Rely-X ARC.

\section{Conclusão}

O grupo liga de Ni-Cr/Panavia F em superfície tratada se comportou melhor em termos de adesividade.

Termos de indexação: Resinas compostas. Cimentos dentários. Resistência ao cisalhamento.

\footnotetext{
${ }^{1}$ Universidade Federal Fluminense, Faculdade de Odontologia. Rua Mario Santos Braga, 28, Centro, 24020-140, Niterói, RJ, Brasil. Correspondência para / Correspondenceto: CB SILVA. E-mail: <camillabottino@yahoo.com.br>. Universidade Federal Fluminense, Centro de Ciências Médicas, Laboratório de Biotecnologia Aplicada. Niterói, RJ, Brasil.
} 


\section{INTRODUCTION}

Bonding is a technical procedure through which it is sought to affix a restoration built outside the mouth (indirect) on to teeth that have been suitably prepared, by means of a bonding material ${ }^{1}$, the performance of which has a direct influence on the clinical success of the treatment.

As well as providing retention for the prosthesis, the cement is responsible for the marginal sealing of the interface between the tooth and the restoration², contributing to the maintenance of the physical and biological properties of the structures being joined together ${ }^{3}$. The choice of bonding agent should be guided by a set of beneficial aspects such as: thickness of film, solubility, elastic modulus, flow, bonding and therelease of fluoride ${ }^{4}$

They should also have adequate marginal sealing, high tensile and compressive strength, adequate settingand working times, be radiopaque and have good optical properties ${ }^{5}$.

Resin bonds may be classified as: photopolymerizable, chemically activated or dual-cure ${ }^{6}$. In addition to the classification in relation to setting reaction, they can also be classified in terms of the size of the particles: microfilled and microhybrids?

Of the bonding agentscurrently available, dualcure resin cements are the ones chosen for cementing indirect restorations, particularly esthetic restorations, while for indirect restorations, chemically-activated metal cements are generally recommended ${ }^{8}$.

Resin cements are composed of a Bis-GMA (bisphenol A glycidylmethacrylate) or UDMA (urethane dimethacrylate) matrixcombined with other monomers of lower molecularweight, such as TEGDMA (triethylene glycoldimethacrylate). Bi-functional resin monomers also exist with hydrophilic functional groups, HEMA (hydroxyethyl methacrylate) and 4-META (4-Methacryloxyethyl-trimelliticanhydride), which modify the organic composition of the resin cement compared with compound resins, and promote the mechanical bonding with the dentin surface, which is frequently exposed on prepared teeth ${ }^{9}$. Inorganic matter(glass and colloidal silica particles) treated with silane can also be found in their composition ${ }^{10}$.

The Panavia cement is a kind of resin composite formed by a liquid (monomer) and a powder (polymer and inorganic matter). The chemical structure and the use of the bonding agent MDP (methacryloyloxydecyldihydrogen phosphate) of this cement exhibited an excellent bond with the dentin (without acid conditioning), varnish (conditioned), Ni-
$\mathrm{Cr}$ sandblastedwith aluminum oxide (Now-Chrome-l), smooth gold alloy(Casting-Gold), gold alloy sandblastedwith aluminum oxide (Casting-Gold) and porcelain (VitaOpaque) ${ }^{11}$.

Several techniques are available which seek to promote a growth in surface irregularity with the aim of improving the metal-cement bond, such as chemical attack, electrolytic attack and aluminum oxide sandblasting. The latter is the most simple and least expensive method for creating micro-retention and for this reason it is also the one most frequently used ${ }^{12-13}$

In the beginning, the form of retention most frequently employed was macro-mechanical and the cements were basically composite resins that were diluted or with no load. Later on, micro-mechanical treatments were perfected that permitted greater efficiency and spread of adhesive prostheses. At the present time, resin cements are specifically manufactured for cementing fixed prostheses ${ }^{14}$, as their chemical and mechanical characteristics ${ }^{15}$ have a strong influence on the strength of the bond achieved and, moreover, the emergence of new conditioning agents provides greater simplicity when performing superficial metal alloytreatments ${ }^{16}$.

Several forms of bond may be used to promote the retention of the resin on the metal surface: macromechanical (perforation, screens, spheres, rough surfacewith particles); micro-mechanical (aluminum oxide sandblasting ${ }^{17-19}$ ), electrolyticattack ${ }^{18}$ (roughening using diamond burs ${ }^{17}$ ); chemical (primers for meta $1{ }^{19}$ andsilanes ${ }^{17,19-20}$ ) andsurface-modified layers (tin electrodeposition ${ }^{18}$, silanization ${ }^{18-20}$ ). These treatments may be used separately or in combination ${ }^{19}$.

Several studies have compared the shear bond strengthof resin cements 17-18,21-22. However, the choice of bonding system and cementing agent is still a huge challenge for clinics. While the volume of materials available in the marketplace is very large, the knowledge of their long-term behavior is scant ${ }^{23}$.

The goal of this study was to compare the bond strength of two dual-cure resin cements to the $\mathrm{Ni}-\mathrm{Cr}$ metal alloy, using test specimens with and without any surface treatment.

\section{METHODS}

\section{Resin cements}

In order to carry out the exercise, two resin cements were used (Panavia F Kuraray, Japan, batch 202348 and RelyX ARC, 3M, Germany, batch 1225400611) recommended for the fixture of indirect restorations. 


\section{Metal alloy}

To produce the samples, a Nickel-Chrome alloy was used (Wironia Light, Bego, Bremen, Germany), sold in the form of cylinders for making metal-ceramic restorations.

\section{Casting in order to obtain the test specimens (TS)}

Forty pairs of test specimens $10 \mathrm{~mm}$ wide by $7 \mathrm{~mm}$ high by $2.5 \mathrm{~mm}$ thick were cast into a Nickel-Chrome alloy, Wironia ${ }^{\circledR}$ light (Bego, Bremen, Germany).

A silicon matrix was made from a wax prototype (Bego, Bremen, Germany). The wax was inserted into the silicon matrix obtaining 80samples. After they were removed from the matrix, the test specimens were inserted in a Bellavest lining (Bego, Bremen, Germany). The assemblage was then taken to a Bravac furnace(São Paulo, SP, Brazil) to eliminate the wax and to produce the negative mold of the part to be cast, using the lost wax technique at a suitable temperature $\left(950^{\circ} \mathrm{C}\right)$. Once heated, the ring was connected toa Fornax T centrifuge via electromagnetic induction (Bego, Bremen, Germany) where the casting took place.

Once the ring had cooled, it was opened and the part was removed from the lining and the test specimens were cut away from the sprue, cleaned with ultrasound using only isopropyl alcohol, for ten minutes.

\section{Procedure for bonding the metal parts}

The test specimens were divided into 4 groups of 10 pairs.

\section{Experimental group}

G 1 - Panavia $F$ (KURARAY), without aluminum oxide blasting

G 2 - Panavia F (KURARAY), with aluminum oxide blasting

G 3 - RelyX ARC (3M), without aluminum oxide blasting

G 4 - RelyX ARC (3M), with aluminum oxide blasting

The cleaning of the test specimens in groups 1 and

3 was carried out using ultrasound with isopropyl alcohol. The cementing technique was carried out in accordance with manufacturers' instructions. After cementing, the test specimens were placed in an oven (De Leo, Rio Grande do Sul, Brazil) at $37^{\circ} \mathrm{C}\left( \pm 2^{\circ} \mathrm{C}\right)$ for 24 hours in a humidifier. The mechanical assay was conducted in a K500SMPuniversally assay machine (Kratos, São Paulo, Brazil) and the data were tabulated and sent for statistical analysis.

After the assay, the test specimens were observed and capturedunder an optical microscope(Anatomic
Opton Stereo Microscopic, Stuttgart, Germany) with a magnification of $1000 x$ in order to establish the type of fracture.

In groups 2 and 4 , the test specimens were sandblasted with aluminum oxide with particles of $50 \mu \mathrm{m}$ at a fixed distance of $5 \mathrm{~cm}$, for a period of 20 seconds, pressure of 2 bar, rinsed in running water for 5 seconds and dried with a jet of air. The cleaning was carried out via ultrasound, all the procedures being carried out as per groups 1 and 3.

Panavia Fluoro resin cement: following the cleaning procedure, Alloy Primer (liquid A and liquid B) was applied to the metal and dried for approximately 60 seconds, then equal amounts of paste $A$ and paste $B$ were mixed for 20 seconds. Once manipulated, it was applied to the pieces; any excess was removed and light-activated (RADII PLUS, SDI, São Paulo, Brazil) for 40 seconds at a pre-calibrated light intensity of $500 \mathrm{~mW} / \mathrm{cm}^{2}$. Oxiguard was then applied. After waiting for 3 minutes, the protective gel was removed.

Rely X ARC resin cement: after the cleaning procedure, pastes $A$ and $B$ were mixed for 10 seconds until a homogeneous mass was obtained, which was then applied to the surface of the metal parts. The excess was removed and a pressure of $20 \mathrm{~N}$ applied for 10 minutes. Following the application of pressure, a light-activating device was used for 40 seconds at a pre-calibrated light intensity of $500 \mathrm{~mW} / \mathrm{cm}^{2}$.

Mechanical assay: The assay that was selected was the shear assay at a speed of $0.5 \mathrm{~mm} / \mathrm{min}$, using the K500SMPuniversal assay machine (Kratos, São Paulo, Brazil), with a cell load of $100 \mathrm{Kgf}$. The alignment of each specimen was done in such a way as to avoid an unequal distribution of stress during the application of force, so in the tensile test a slow, homogeneous load was applied aligned at an angle of $90^{\circ}$ in relation to the planed surface substrate. The assay was performed until the point the adhesive filed, characterized by the displacement of the bonding agents of the two metal pieces.

\section{RESULTS}

A visual inspection of the optical microscope images showed a mixed adhesive-predominant fracture pattern for Rely $X$ ARC (Figure 1) and mixed cohesivepredominant pattern for Panavia $\mathrm{F}$ (Figure 2).

For the shear assay, the load cell used was $100 \mathrm{kgfand}$ a speed of $0.5 \mathrm{~mm} / \mathrm{min}$, ambient temperature of $25^{\circ} \mathrm{C}$ and a pre-load of $5 \mathrm{~N}$. 


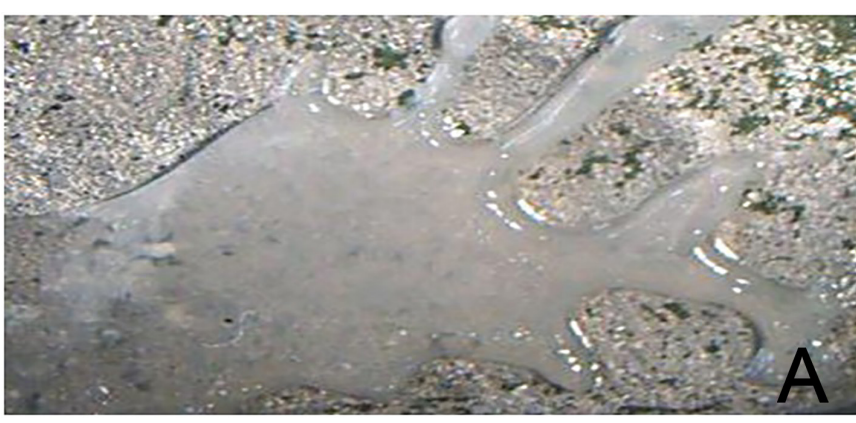

Figure 1. Optical micrograph - Rely X ARC.

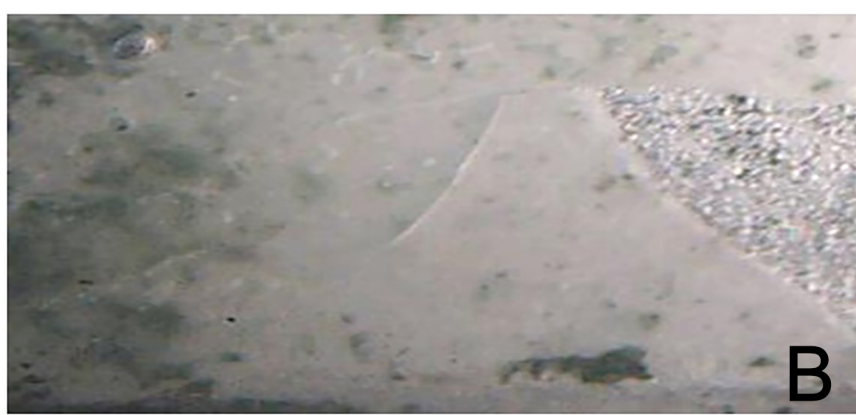

Figure 2. Optical micrograph- Panavia F.

Table 1. Two-way variance analysis at maximum pull-out force.

\begin{tabular}{lccccc}
\hline Source of variation & Sum of the squares & Degrees of freedom & Mean square & F Statistic & $p$-value \\
\hline Cement & 1944.63 & & 1944.63 & 23.262 & 0.0007 \\
Blasting & 3509.25 & 1 & 3509.25 & 41.979 & 10.853 \\
$\begin{array}{l}\text { Cement v. Blasting } \\
\text { interaction }\end{array}$ & 907.26 & 1 & 907.26 & & 0.0001 \\
Residues & 3009.46 & 36 & 83.60 & \\
Total & 9370.60 & 39 & & \\
\hline
\end{tabular}

The Variance Analysis shows a statistically significant difference $(p<0.05)$ between the cements, between working with blasting and without blasting, and through the interaction of the cement and the use of blasting, or otherwise.
Table 2 provides a statistical description (mean, SD $\left(^{*}\right)$, minimum, maximum, median and iqr $(*)$ ) of the maximum pull-out in the groups. Figure 3 describes the box plot.

Table 2. Parametric description of the maximum pull-out force.

\begin{tabular}{lcccccccc}
\hline Cement & Blasting & $\mathrm{n}$ & mean & $\mathrm{SD}\left({ }^{*}\right)$ & min & max & median & iqr $\left(^{*}\right)$ \\
\hline \multirow{2}{*}{ Rely X } & Yes & 10 & 15.3 & 8.23 & 1.9 & 29.2 & 16.3 & 11.0 \\
& No & 10 & 6.1 & 5.12 & 0.4 & 17.0 & 5.0 & 10.3 \\
\multirow{2}{*}{ Panavia } & Yes & 10 & 38.8 & 13.03 & 19.7 & 54.0 & 38.1 & 21.4 \\
& No & 10 & 10.6 & 8.40 & 2.2 & 27.1 & 8.4 & 8.7 \\
\hline
\end{tabular}

(*) - SD: standard deviation; iqr: interquartile range(based on the Tukey hinges).

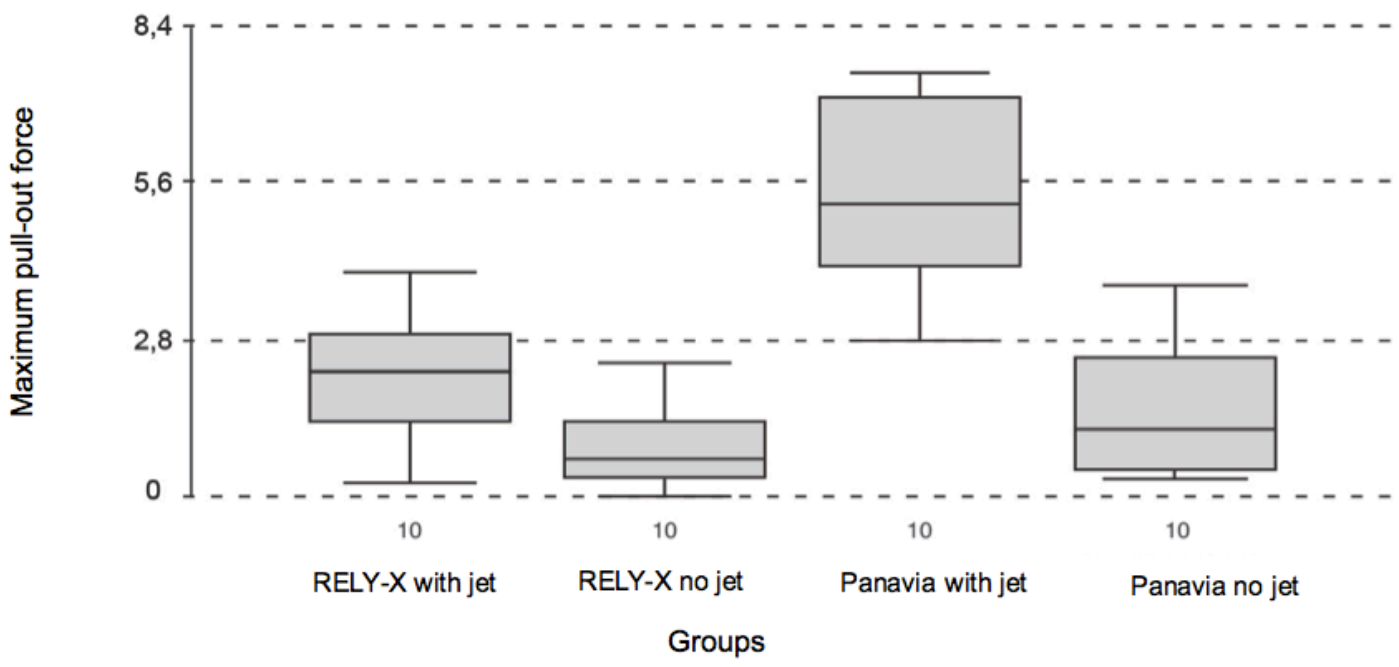

Figure 3. Graphical description (by means of box and whisker diagrams: boxplots). 


\section{DISCUSSION}

The cementing of a prosthetic restoration is the final step of a series of procedures including dental preparation, molding, acquisition of the mold and the laboratory stages of making the restoration. The ultimate success will depend on the correct selection and manipulation of the bonding agent ${ }^{24}$.

The present study sought to compare the bonding strength of two dual-cure resin cements to aNi-Cr alloy, in specimens that received surface treatment and those that did not.

The choice of alloy in this study was based on the properties of the $\mathrm{Ni}-\mathrm{Cr}$ alloy because this has generally been the material of choice for making adhesive prostheses ${ }^{17}$. At the present time, there are numerous studies that make use of this alloy ${ }^{21-22}$

Resin cements are important because they are highly adhesive and resistant to the dislodgement of the restoration ${ }^{5}$. The phosphate monomer 10-MDP, which emerged in the $1980 \mathrm{~s}^{11}$, as a component of the Panavia bonding adhesive has continued to be a benchmark for the type of metal-resinbond. They can be very useful when the geometric design of the preparations does not provide adequate retention and stability ${ }^{5}$.

As an adhesive prosthesis is subjected to forcesright fromthe initial cementation, the present study performed a mechanical assay 24 hours after cementation, acquiring recent data of the cement and the part.

The use of aluminum oxide blasting to clean the prosthetic parts and the increase in micro-mechanical retention prior to cementation has become a commonly used procedure since a significant increase in bond strength has been noted between the metal and the resin, when the metal's surface is sandblasted with aluminum oxide ${ }^{13}$.

The present study proposed to analyze the sandblasting with $50 \mu \mathrm{AL}_{2} \mathrm{O}_{3}$ particles, applied to a $\mathrm{Ni}-\mathrm{Cr}$ alloy, the shear resistance of the alloy to the cements Panavia F and Rely X ARC and the consequent fracture pattern. Knowing that the effect of blasting with aluminum oxide and the type of resin cement(with or without MDP) demonstrated that the highest and best adhesive strength values were obtained after blasting and cementation with MDP-based cement ${ }^{25}$. These data contributed to the findings in our study, in which Panavia $\mathrm{F}$ sandblasted with $\mathrm{AL}_{2} \mathrm{O}_{3}$ obtained the best results. The phosphate ester group of the adhesive monomer MDP bonds directly with metallic oxides, thus they suggest a chemical bond between the MDP and the oxides of aluminum ${ }^{25}$

A mixed fracture pattern with cohesive predominance of Panavia $\mathrm{F}$ was obtained in this study, a constant feature in studies using this type of resin cement 22,26 .

The Rely X ARC showed mixed fractures with adhesive predominancein keeping with the literature ${ }^{27}$.

The fracture pattern confirms the statistical data in this study in which group 2 presented statistically higher tensile strength values in comparison with the resin cement Rely X ARC.

Given the great variety of available bonding agents, the dental professional cannot use just one bonding agent for all cases, and should be alert to the inherent characteristics in each clinical situation, so that he/she may correctly selectthe most suitable technique and bonding agent ${ }^{28-29}$.

\section{CONCLUSION}

Based on the methodology applied, the experimental conditions and in accordance with the proposition, it was concluded that:

The surface treatment of the metal promoted a more effective bonding of the resin cements Panavia Fluoro Cement and Rely X ARC to the Ni-Cralloy when compared to untreated surfaces. The cement Panavia Fluor demonstrated superior bonding, when compared to the Rely X ARC, on treated metal surfaces.

\section{Collaborators}

CB SILVA was responsible for the experimental work and composition of the article. DM SALIM described the methodology, collaborated in the laboratory activities and also the composition of the article. GM KAMMER assisted with the statistical analysis and took part in the composition of the article. W CARVALHO supervised the laboratory study and took part in the composition of the article. 


\section{REFERENCES}

1. Leal DP, Severo AMR, Burgos MEA, Menezes MRA, Loretto NRM, Patrício SF. Ionômero de vidro ou cimento de fosfato de zinco na cimentação de restaurações metálicas fundidas. Odontol Mod. 1995;22(3):6-9.

2. Soares CJ, Quagliatto OS, Campos RE. Cimento de ionômero de vidro: características do material e aplicações clínicas. In: Busato ALS. Dentística: filosofia, conceitos e prática clínica. São Paulo: Artes Médicas; 2005.

3. Morais MCS, Pandolfi RF, Pegoraro LF, Valle AL, Freitas CA. Resistência à remoção por tração e desajuste de infra-estruturas para coroas metalocerâmicas, analisando dois tipos de cimentos. Rev Fac Odontol Bauru. 1994;2(4):7-14.

4. Gerdullo ML, Nakamura SCB, Suga RS, Navarro MFL. Resistência à compressão e à tração diametral de cimentos de ionômero de vidro indicados para cimentação. Rev Odontol Univ São Paulo. 1995;9(1):17-22.

5. Bottino MA, Quintas AF, Miyashita E, Giannini V. Estética em reabilitação oral: metal free. São Paulo: Artes Médicas; 2001.

6. Baratieri LN, Monteiro S. Odontologia restauradora: fundamentos e técnicas. São Paulo: Editora Santos; 2010.

7. Cardoso RJA, Gonçalves EAN. Estética: arte, ciência e técnica. São Paulo: Artes Médicas; 2002.

8. Busato ALS, Hernandez PAG, Macedo RP. Dentística: restaurações estéticas. São Paulo: Artes Médicas; 2002.

9. Góes MF. Cimentos resinosos. In: Restaurações de resina composta em dentes posteriores. São Paulo: Artes Médicas; 1998. p. 169-76.

10. Ben-Amar A, Liberman R, Apatowsky U, Pilo R. PH changes of glass-ionomer lining materials at various time intervals. J Oral Rehabil. 1999;26(11):847-52. doi: 10.1046/j.13652842.1999.00480.x

11. Omura I, Yamaguchi J, Harada I, Wada T. Adhesive and mechanical properties of a new dental adhesive. J Dent Res. 1984;83:233.

12. Pegoraro $\mathrm{FL}$, Bonfante $\mathrm{G}$, Ferreira $\mathrm{PM}$, Valle $\mathrm{AL}$, Pandolfi $\mathrm{RF}$, Mondelli J. Prótese fixa adesiva indireta. RGO - Rev Gaúch Odontol. 1986;34(4):339-42.

13. Chung $\mathrm{KH}$, Hwang $\mathrm{YC}$. Bonding strengths of porcelain repair systems with various surface treatments. J Prosthet Dent. 1997;78(3):267-74. doi:10.1016/S0022-3913(97)70025-8

14. Yoshida K, Sawase T, Watanabe L, Atsuta M. Shear bond strengths of four resin cements to cobalt-choromium alloy. Am J Dent. 1995;8(6):285-8. doi: 10.4012/dmj.2012-051

15. Yoshida K, Kamada K, Taira Y, Atsuta M. Effects of three adhesive primers on the bond strengths of four light-activated opaque resins to noble alloy. J Oral Rehabil. 2001;28(2):168-73. doi: 10.1046/j.1365-2842.2001.00662.x
16. Antoniadou M, Kern M, Strub JR. Effect of a new metal primer on the bond strength between a resin cement and two highnoble alloys. J Prosthet Dent. 2000;84(5):554-60. doi:10.1067/ mpr.2000.109986

17. Cobb DS, Vargas MA, Fridrich TA, Bouschlicher MR. Metal surface treatment: characterization and effect on composite-tometal bond strength. Oper Dent. 2000;25(5):427-33.

18. Ozcan M, Pfeiffer P, Nergiz I. A brief history and current status of metal-and ceramic surface-conditioning concepts for resin bonding in dentistry. Quintessence Int.1998;29(11):713-24.

19. Watanabe $T$, Ino S, Okada S, Katsumata $Y$, Hamano N, Hojo $S$, et al. Influence of simplified silica coating method on the bonding strength of resin cement to dental alloy. Dent Mater J. 2008;27(1):16-20. doi: 10.4012/dmj.27.16

20. Matinlinna JP, Vallittu PK. Silane based concepts on bonding resin composite to metals. J Contemp Dent Pract. 2007;8(2):1-8.

21. Ferreira JJB, Prates LHM, Calvo MCM. Avaliação da resistência da união de fundições de níquel-cromo fixadas com cimentos resinosos: efeito da aplicação do "primer" silano e do adesivo. RGO - Rev Gaúch Odontol. 2006;54(3):234-9.

22. Atta MO, Smith BG, Brown D. Bond strengths of three chemical adhesive cement adhered to a nickel-chromium alloy for direct bonded retainers. J Prosthet Dent. 1990;63(2):137-43. doi:10.1016/0022-3913(90)90096-し

23. Carvalho RM, Pegoraro TA, Tay FR, Pegoraro LF, Silva NR, Pashley $\mathrm{DH}$. Adhesive permeability affects coupling of resin cements that utilise self-etching primers to dentine. J Dent. 2004;32(1):55-65. doi:10.1016/j.jdent.2003.08.003

24. Maia LG, Vieira LCC. Cimentos resinosos: uma revisão da literatura. JBD J Bras Dentística \& Estética. 2003;2(7):258-62.

25. Wolfart M, Lehmann F, Wolfart S, Kern M. Durability of the resin bond strength to zirconia ceramic after using different surface conditioning methods. Dent Mater. 2007;23(1):45-50. doi:10.1016/j.dental.2005.11.040

26. Watanebe F, Powers JM, Lorey RE. In vitro bonding of prosthodontic adhesives to dental alloys. J Dent Res. 1988;67(2):479-83. doi: 10.1177/00220345880670020901

27. Garcia RN, Góes MF, Giannini M. Avaliação da resistência de união ao microcisalhamento entre compósitos restauradores e cimentos resinosos. RSBO. 2008;5(2):28-36.

28. Ribeiro $C M B$, Lopes $M W F$, Farias $A B L$, Cabral BLAL, Guerra CMF. Cimentação em prótese: procedimentos convencionais e adesivos. Int J Dent. 2007;6(2):58-62.

29. Hayassy A, Lacerda RASV, Fraga RC, Rabello FH. Evaluation of adhesive metal alloys cementing through the human tooth a shearing test. Ciência Atual. 2013;1(1):32-97.

Received on: 29/8/2013 Final version resubmitted on: 12/7/2014 Approved on: 16/9/2014 